\title{
Use of monoclonal antibodies against Hendra and Nipah viruses in an antigen capture ELISA
}

\author{
Cheng-Feng Chiang ${ }^{1}$, Michael K Lo², Paul A Rota² ${ }^{2}$ Christina F Spiropoulou ${ }^{1}$ and Pierre E Rollin*1
}

\begin{abstract}
Background: Outbreaks of Hendra (HeV) and Nipah (NiV) viruses have been reported starting in 1994 and 1998, respectively. Both viruses are capable of causing fatal disease in humans and effecting great economical loss in the livestock industry.

Results: Through screening of hybridomas derived from mice immunized with $\gamma$-irradiated Nipah virus, we identified two secreted antibodies; one reactive with the nucleocapsid (N) protein and the other, the phosphoprotein (P) of henipaviruses. Epitope mapping and protein sequence alignments between NiV and HeV suggest the last 14 amino acids of the carboxyl terminus of the $\mathrm{N}$ protein is the target of the anti- $\mathrm{N}$ antibody. The anti-P antibody recognizes an epitope in the amino-terminal half of $\mathrm{P}$ protein. These monoclonal antibodies were used to develop two antigen capture ELISAs, one for virus detection and the other for differentiation between NiV and HeV. The lower limit of detection of the capture assay with both monoclonal antibodies was $400 \mathrm{pfu}$. The anti-N antibody was used to successfully detect NiV in a lung tissue suspension from an infected pig.
\end{abstract}

Conclusion: The antigen capture ELISA developed is potentially affordable tool to provide rapid detection and differentiation between the henipaviruses.

\section{Background}

Since their first occurrences in 1994 and 1998 respectively, the Hendra $(\mathrm{HeV})$ and Nipah $(\mathrm{NiV})$ viruses have caused recurrent outbreaks throughout northeastern Australia and southern Asia [1-5]. Fruit bats of the genus Pteropus have been identified as the primary reservoirs of these viruses [6-9]. Thoroughbred horses and farmed pigs, respectively, were the intermediate hosts between the bat reservoir and humans in the initial outbreaks $[10,11]$. Since then, several $\mathrm{HeV}$ infections had only occurred in horses and no intermediate host was identified in the subsequent NiV outbreaks in India and Bangladesh [5,12-14].

Four fatalities have been reported in 7 cases of human $\mathrm{HeV}$ infections [15]. Human case fatalities in $\mathrm{NiV}$ outbreaks varied from 38\% in Malaysia up to $92 \%$ in Bangladesh $[2,10,12,13]$. The higher case fatalities in the Bangladesh outbreaks could be attributable to bias in selection of admissible patients and lack of adequate

* Correspondence: pyr3@cdc.gov

1 Special Pathogens Branch, Division of Viral and Rickettsial Diseases, Centers for Disease Control and Prevention, Atlanta, Georgia, USA

Full list of author information is available at the end of the article healthcare system [2]. Both $\mathrm{HeV}$ and $\mathrm{NiV}$ are categorized as Biosafety Level 4 (BSL4) Select Agents by the US National Select Agent Program [16,17].

Because $\mathrm{HeV}$ and $\mathrm{NiV}$ share unique genetic and antigenic features, a distinct genus Henipavirus, was created within the family Paramyxoviridae [18-20]. Alignments of $\mathrm{NiV}$ and $\mathrm{HeV}$ amino acid sequences demonstrate similarities ranging from $92.1 \%$ for the nucleocapsid $(\mathrm{N})$ protein to $67.6 \%$ for the phosphoprotein $(\mathrm{P})[19,21]$. The divergence in amino acid sequences between $\mathrm{NiV}$ and $\mathrm{HeV} \mathrm{P}$ proteins suggests that it is a potential candidate antigen for differential detection of $\mathrm{NiV}$ and $\mathrm{HeV}$.

Infections by $\mathrm{NiV}$ or $\mathrm{HeV}$ in humans and animals can be confirmed by serologic tests as well as by detection of viral proteins, viral RNA or by virus isolation [16]. The most commonly used serologic assays are ELISAs using infected cell lysate antigens and the specificity of these IgG and IgM ELISA systems for detecting infection with henipaviruses approaches 95\% [16]. Recombinant N protein has been used as an alternative antigen for serological detections of henipaviruses in the absence of a BSL4 facility required to generate $\mathrm{NiV}$ or $\mathrm{HeV}$ infected cell lysate [16,22-25]. Results from ELISA assays can be con- 
firmed by other serologic tests including plaque reduction neutralization [26,27]. A number of sensitive RTPCR assays have been described for detection of viral RNA $[28,29]$ and these have been used to support outbreak investigations and research. Viral antigen capture ELISA would also provide a high throughput format at relatively low cost. Such assays could be adapted into bedside or pen-side tests to perform rapid detection of henipaviruses in field or clinical settings [30,31].

In this report, we have taken the first steps to develop antigen capture tests for $\mathrm{HeV}$ and $\mathrm{NiV}$ by characterizing two monoclonal antibodies against the Henipavirus $\mathrm{P}$ and $\mathrm{N}$ proteins. The $2 \mathrm{~B} 10 \mathrm{p} 4$ antibody specifically binds and captures $\mathrm{HeV}$ P/V/W proteins. The anti-N antibody 1A11 $\mathrm{C} 1$ captures proteins from $\mathrm{HeV}$ and both $\mathrm{NiV}$ Malaysia and Bangladesh strains with high sensitivities, and was able to detect $\mathrm{NiV}$ antigen from a pig lung specimen frozen since the Malaysian NiV outbreak. The advantage of this cost-effective assay is that it enables rapid processing of large numbers of specimens, and it can complement the current diagnostic tools for henipaviruses used both in the field and the laboratory.

\section{Results}

\section{Specificities of monoclonal antibodies to henipaviruses}

During the initial rounds of cloning and screening of the hybridomas, two hybridomas (1A11 and 2B10) were selected for their ability to recognize major proteins from $\mathrm{HeV}$ and NiV infected Vero cell lysates (Figure 1A). The 1A11 antibody recognized a protein similar in size to the $\mathrm{N}$ protein $(\sim 58 \mathrm{kDa})$ from $\mathrm{HeV}$ as well as from both strains of NiV (Malaysia and Bangladesh). The 2B10 antibody detected a protein of slightly less than $100 \mathrm{kDa}$ from $2 \mathrm{NiV}$ strains and $\mathrm{HeV}$. It also weakly reacted with a protein similar in size to the $\mathrm{N}$ protein in all infected lysates (Figure 1A). These two hybridomas were subjected to further cloning and screening against cell lysates containing individual $\mathrm{NiV}$ Malaysia protein P, V, W, C or N, that were expressed from plasmid DNA. The resulting antibody from $1 \mathrm{~A} 11 \mathrm{C} 1$ was specific for the $\mathrm{N}$ protein (Figure $1 B)$. Antibody from $2 \mathrm{~B} 10 \mathrm{p} 4$ strongly recognized the $\mathrm{P}$ protein (migrated with apparent molecular weights between 80 and $98 \mathrm{kDa}$ ) and a more weakly product of approximately $\sim 40 \mathrm{kDa}$, which likely represents a degradation or premature termination product. In addition, $2 \mathrm{~B} 10 \mathrm{p} 4$ could also weakly detect the $\mathrm{V}$ and $\mathrm{W}$ proteins (55 kDa, Figure 1B). The $C$ protein which is translated from an alternative reading frame on the $\mathrm{P}$ gene was not recognized by either antibody (Figure 1B). Antibody isotypes of $1 \mathrm{~A} 11 \mathrm{C} 1$ and $2 \mathrm{~B} 10 \mathrm{p} 4$ were determined as IgG2a and IgG1, respectively.

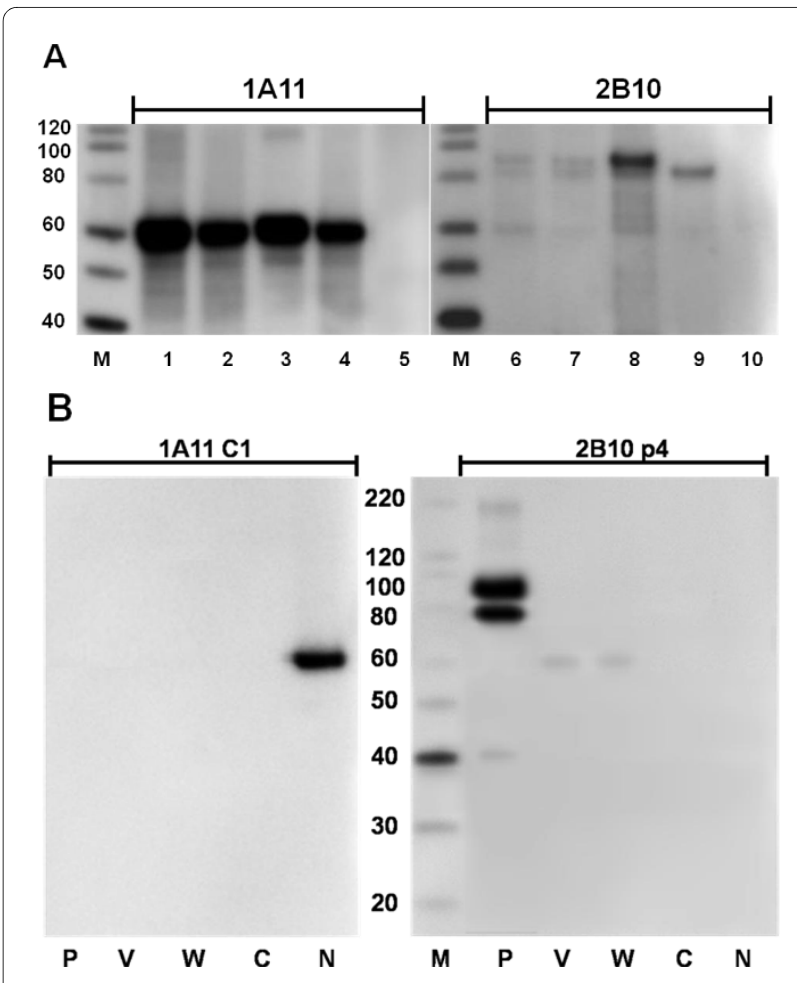

Figure 1 Characterizations of antibodies produced by hybridomas. (A) The 4-12\% gradient gels were loaded with cell lysate equivalent to $2 \mu \mathrm{g}$ of protein in each lane as follows, lane 1 and 2 (also lane 6 and 7) represent 2 preparations of NiV Malaysia infected Vero cell lysates; lane 3 and 8, NiV Bangladesh infected Vero cell lysate; lane 4 and 9, HeV infected Vero cell lysate; lane 5 and 10, control Vero cell lysate. After gel separation and transferring, membranes were probed with culture supernatant from $1 \mathrm{~A} 11$ and 2B10. (B) 293T cells were transfected with NiV Malaysia P, V, W, C or N proteins expressed from plasmids. Ten $\mu \mathrm{L}$ of each cell lysate was separated by SDS-PAGE. Monoclonal antibodies purified from cloned hybridomas were diluted 1 to 2000 and incubated with transferred membranes. Lane M, ladder of MagicMark ${ }^{\mathrm{TM}}$ XP Western Protein Standard from Invitrogen.

\section{Epitope mapping of $1 \mathrm{~A} 11 \mathrm{C} 1$ and $2 \mathrm{~B} 10 \mathrm{p} 4$}

To determine the linear epitope of monoclonal antibody 1A11 C1, 24 or 25 -mers of non-overlapping peptides spanning over the entire $\mathrm{N}$ protein sequence of $\mathrm{NiV}$ were screened by direct ELISA. Only a C-terminal peptide (a.a. 509-532) yielded specific signals above the $10 \mathrm{ng} / \mathrm{ml}$ concentration of plate-coated peptide (Figure 2). The epitope in this $\mathrm{C}$-terminal region was not only detected by $\mathrm{NiV}$ hyperimmune mouse ascites fluid (HMAF) but also by $\mathrm{HeV} \mathrm{HMAF}$, rabbit anti-HeV serum and a pool of $\mathrm{NiV}$ sero-positive swine sera from the 1999 Malaysia outbreak (Figure 3). The overall pattern of shared epitopes among polyclonal antibodies could be observed regardless of the source of immunogen ( $\mathrm{NiV}$ or $\mathrm{HeV}$ ) or the mammals from which the antibodies were generated (Figure 3). 


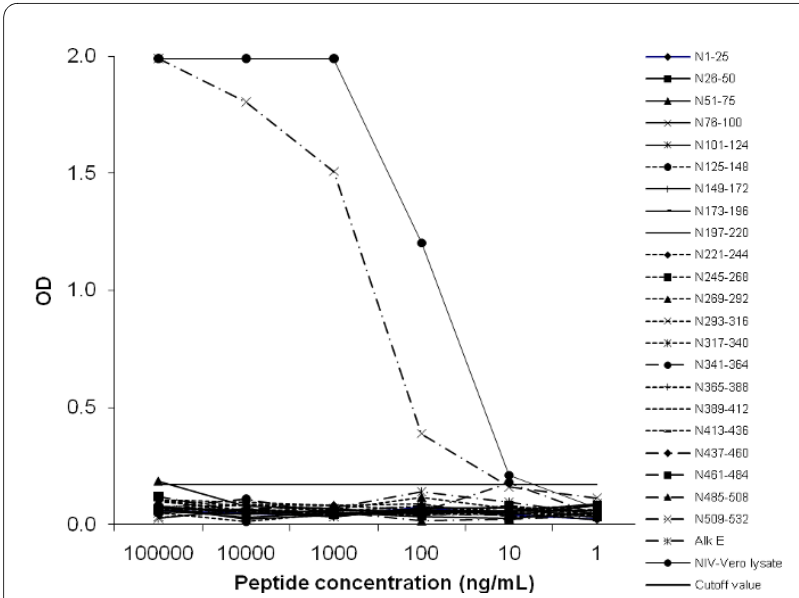

Figure 2 Epitope mapping of $\mathrm{mAb} 1 \mathrm{~A} 11 \mathrm{C} 1$ using direct ELISA Synthetic peptides corresponding to the complete NiV N protein sequence (a.a. 1-532) were serial diluted and coated at concentration from $1 \mu \mathrm{g}$ to $0.1 \mathrm{ng}$ per well $(100 \mu \mathrm{L}$ in volume). A peptide from Alkhurma virus E protein (AlkE, a.a. 143-168) was included as negative control and signal cutoff value $(0.17)$ was calculated based on readings from this peptide. NiV infected Vero lysate diluted 10 fold to $10^{5}$ fold were served as positive control.

Interestingly, the rabbit anti-HeV serum bound to a distinct epitope (a.a.101-124) which was not recognized by antibodies generated from other animal species (Figure 3). Several human convalescent sera from the 1999 outbreak did not react to the $\mathrm{C}$ terminal peptide of the $\mathrm{N}$ protein (Figure 3).

The $\mathrm{V}$ and $\mathrm{W}$ proteins of henipaviruses are transcribed from the same reading frame as the $P$ protein until reaching the internal mRNA editing site in the P gene [32-34].

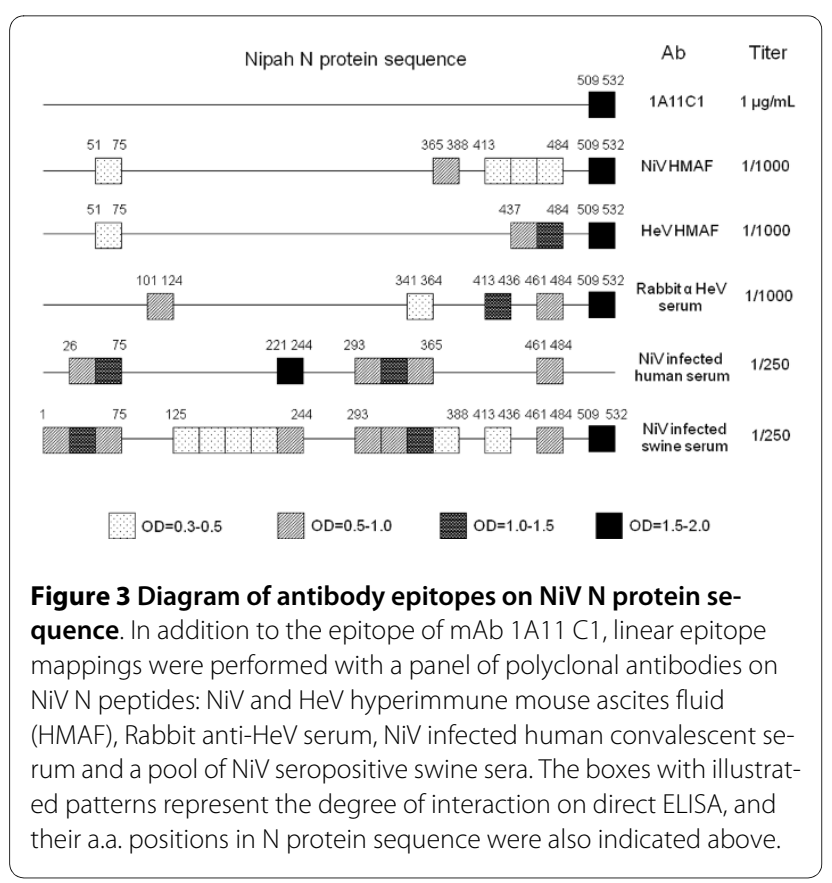

We have shown that $2 \mathrm{~B} 10 \mathrm{p} 4$ recognized protein products generated from $\mathrm{P}$ gene transcripts (NiV P, V, and W proteins) by Western blot (Figure 1B). This suggests that the epitope of $2 \mathrm{~B} 10 \mathrm{p} 4$ is located within the common Nterminal sequence (a.a. 1-407) of these proteins. However, linear epitope mapping over this region did not result in any peptide binding even with the inclusion of reported single phosphorylated site at Ser-240 [21] (Data not shown).

\section{Antigen capture from infected Vero cell lysates}

Monoclonal antibodies 1A11 C1 and 2B10 p4 were further analyzed to test their abilities to capture native viral proteins on ELISA plates. Antibody $1 \mathrm{~A} 11 \mathrm{C} 1$ was able to detect $\mathrm{NiV}$ Malaysia, $\mathrm{NiV}$ Bangladesh and $\mathrm{HeV}$ from infected Vero cell lysates (Figure 4A, B and 4C). Successful detection of $\mathrm{N}$ proteins was achieved at dilutions ranging 1:1 to 1:7290, with the cutoff value derived from 3 times the standard deviation of the average OD of the uninfected cell lysate controls being 0.2-0.3. The P/V/W specific antibody $2 \mathrm{~B} 10 \mathrm{p} 4$ could only detect $\mathrm{NiV}$ proteins at very low dilutions (1:1 to $1: 270$, Figure $4 \mathrm{~A}$ and $4 \mathrm{~B})$; however, applying infected cell lysate at a dilution less than 1:270 resulted in increased non-specific signals (e.g. Marburg hemorrhage fever (MHF) virus HMAF coated controls in Figure 4A, B and 4C). The 2B10 p4 captured $\mathrm{HeV} \mathrm{P/V/W}$ protein at cell lysate dilutions of $1: 1$ to 1:2340 (Figure 4C).

\section{Sensitivity of antigen capture ELISA}

Serial dilutions of titrated virus stocks (NiV Malaysia prototype and $\mathrm{HeV}$ ) were prepared in buffer containing nonionic detergent and tested on antigen capture ELISA coated with $1 \mathrm{~A} 11 \mathrm{C} 1$ or $2 \mathrm{~B} 10 \mathrm{p} 4$ (Figure $5 \mathrm{~A}$ and $5 \mathrm{~B}$ ). Antibody $1 \mathrm{~A} 11 \mathrm{C} 1$ was capable of capturing $\mathrm{NiV}$ or $\mathrm{HeV}$ at virus titer of $\log 3.6 \mathrm{pfu} / \mathrm{mL}$ ( $400 \mathrm{pfu}$ per well). The anti-P $2 \mathrm{~B} 10 \mathrm{p} 4$ antibody detects $\mathrm{HeV}$ at a comparable sensitivity as $1 \mathrm{~A} 11 \mathrm{C} 1$ (Figure $5 \mathrm{~B}$ ), but had poor ability to bind NiV (Figure 5A) similar to results obtained with the infected Vero cell lysate (Figure 4A). Dilutions of Lassa virus were included as the background control to calculate the cutoff value of the assay ( 0.21 , Figure $5 \mathrm{~A}$ and $5 \mathrm{~B})$.

\section{Detection of NiV in pig tissue by antigen capture ELISA}

In order to evaluate antigen capture ELISA, cell suspensions from $\gamma$-irradiated pig tissue specimens from the Malaysian outbreak in 1999 were prepared as target antigens on plates coated with monoclonal antibody $1 \mathrm{~A} 11$ $\mathrm{C} 1$. The results of the antigen capture assay are shown alongside data from RT-PCR, virus isolation, immunohistochemistry (IHC), and antibody detections [10] in Table 1. A low titer of NiV N antigens was detected in the lung of pig 55 using the antigen capture assay (Table 1). Positive RT-PCR, virus isolation and IHC results also confirmed the existence of $\mathrm{NiV}$ in the lung of this pig (Table 


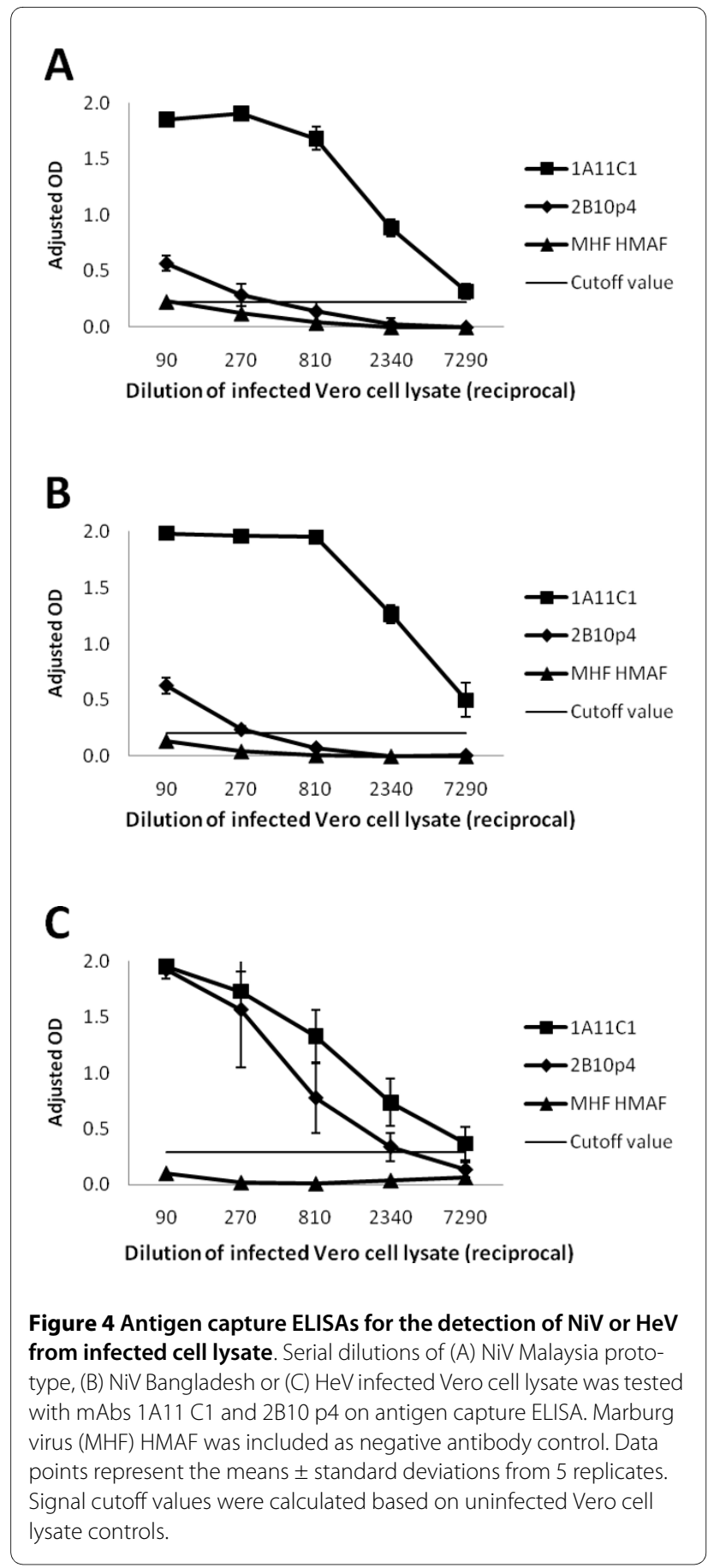

1). However, the antigen capture assay did not detect viral antigen in the lung and brain of Pig 5, although RT-PCR and virus isolation performed at the time of the outbreak confirmed NiV infections in the lung of Pig 5 (Table 1). No virus was detected in the brain, lung, or kidney of Pig 4 and 59 by capture ELISA, RT-PCR, virus isolation, or IHC (Table 1). No IgM or IgG response was detected during the time of outbreak in the serum of these pigs (Table 1). Due to the shortage of outbreak specimens, we were

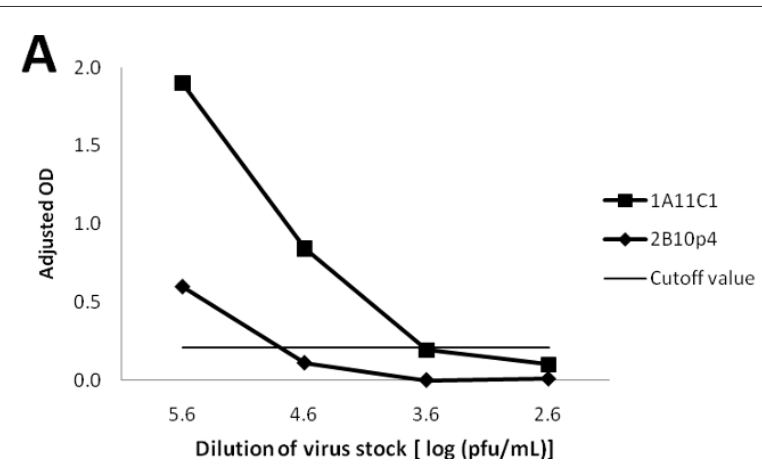

B

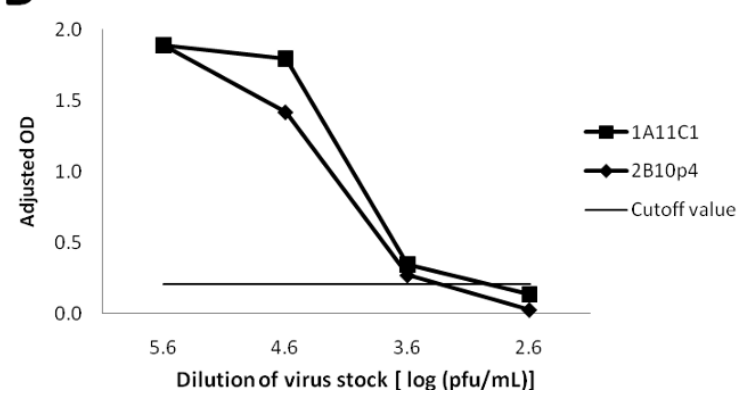

Figure 5 Sensitivities of antigen capture ELISAs for titrated NiV and $\mathrm{HeV}$ stocks. (A) NiV Malaysia prototype stock $\left(4.1 \times 10^{6} \mathrm{pfu} / \mathrm{mL}\right)$ and (B) HeV stock $\left(1.9 \times 10^{6} \mathrm{pfu} / \mathrm{mL}\right)$ were serial diluted onto wells coated with $1 \mathrm{~A} 11 \mathrm{C} 1$ and 2B10 p4. Marburg virus (MHF) HMAF was included as negative antibody control and signals above this antibody control were shown (Adjusted OD). Lassa virus stock ( $\left.1 \times 10^{8} \mathrm{pfu} / \mathrm{mL}\right)$ was used as negative virus control and signal cutoff value was calculated based on its OD readings.

unable to determine the sensitivity and specificity of antigen capture ELISA on tissue samples.

\section{Discussion}

Up until the present, all the reported cases or outbreaks of infection with henipaviruses were within the geographical distribution of Pteropus spp. [6,8,9]. These bats appear to settle into subpopulations with limited interactions among colonies [1]. $\mathrm{NiV}$ and $\mathrm{HeV}$ apparently remain separate within their hosts and respective regions with little overlap [1]. On the other hand, other families of bats were often found coexisting in the same colony with Pteropus. Antibodies reactive with Nipah virus were found in Eidolon dupreanum in Madagascar [35]. Furthermore, other novel henipavirus-like sequences and cross-reacting antibodies have recently been identified in Eidolon helvum from Ghana, West Africa [36,37], which potentially implicates much wider endemic regions of henipaviruses than previously known.

Here we report two monoclonal antibodies that recognized native conformations of $\mathrm{N}$ and $\mathrm{P} / \mathrm{V} / \mathrm{W}$ proteins of henipaviruses. In previous studies, monoclonal antibod- 
Table 1: Diagnostic result of NiV infections in pigsa.

\begin{tabular}{|c|c|c|c|c|c|}
\hline Pig no & Capture ELISA & RT-PCR & Virus isolation & IHCC & $A b^{d}$ \\
\hline 4 & - & - & - & - & - \\
\hline 5 & - & + & + & ND & - \\
\hline 55 & + (lung, 4) & + & + & + & - \\
\hline 59 & - & - & - & - & - \\
\hline
\end{tabular}

ies were produced either through phage display library screening, or using chemically inactivated virus/recombinant viral protein immunizations [22-26,38-40]. The hybridomas in our study originated from mice immunized with $\gamma$-irradiated virus, and the secreted antibodies recognized native viral proteins. Linear epitope mapping on $\mathrm{NiV} \mathrm{N}$ sequence indicates the epitope of $1 \mathrm{~A} 11 \mathrm{C} 1$ is located within the last C-terminal 23 amino acids (a. a.) of the $\mathrm{N}$ protein (509-532). Alignment data of the $\mathrm{C}$ terminal area of $\mathrm{N}$ protein between $\mathrm{NiV}$ and $\mathrm{HeV}$ further indicated that the last 14 a.a. (520-532) were identical between the two viruses [41], and would likely represent the actual epitope. Interestingly, this epitope is located right after the N-P interaction site (a.a. 468-496) on the $\mathrm{N}$ protein [41]. Epitope mapping of other monoclonal antibodies to recombinant $\mathrm{N}$ protein or phage library screening of infected swine sera did not identify the $\mathrm{C}$ terminus of $\mathrm{N}$ protein as a site of antibody recognition [40,42]. In addition, linear epitope mappings against the NiV $\mathrm{N}$ protein sequence using ascites fluids, sera from immunized animals or infected humans/pigs were performed and compared. The $\mathrm{C}$ terminal peptide of $\mathrm{N}$ protein was found to be a strong epitope recognized by all of polyclonal antibodies tested except for $\mathrm{NiV}$ infected human convalescent sera.

Our antigen capture ELISA, using plates coated with anti-N 1A11 C1 antibodies was capable of detecting $\mathrm{HeV}$ and $\mathrm{NiV}$ at a lower limit of detection of $4000 \mathrm{pfu} / \mathrm{mL}$ which is comparable to detection sensitivities reported in other antigen detection ELISAs [43,44]. The 1A11 C1 or 2B10 p4 antigen detection assay also demonstrated its specificity by low background signal cutoff values for uninfected Vero cell lysate and Lassa virus. In addition, when using high dilutions of $\mathrm{NiV} / \mathrm{HeV}$ infected Vero cell lysates ( $\geq 1$ : 300), non-specific signals were kept below background levels when polyclonal antibodies against MHF or Crimean-Congo hemorrhagic fever (CCHF) virus (data not shown) were coated on the plate.

Monoclonal antibody $1 \mathrm{~A} 11 \mathrm{C} 1$ was also shown to capture $\mathrm{NiV}$ from one frozen pig lung specimen from the ini- tial Malaysian NiV outbreak. However, corresponding RT-PCR and virus isolation results obtained at the time of the outbreak suggest the assay failed to identify another infected pig. A previous study had shown virus titers of 5 $\times 10^{7}, 2.5 \times 10^{3}$, and $6.3 \times 10^{5} \mathrm{pfu} / \mathrm{g}$ of swine CSF, lung, and spleen tissues, respectively [45]. In our antigen detection assay, $10 \%$ tissue suspension (wt/vol) was used as the origin of serial dilutions. Virus loads in some tissue may be too low to be detected at this dilution range. Furthermore, viral degradation resulting from long term storage may further compromise the results of antigen capture ELISA. Unfortunately, we were unable to confirm this possibility by repeating RT-PCR and virus isolation since tissue samples were irradiated.

A previous study has described using monoclonal antibodies against $\mathrm{N}$ and $\mathrm{M}$ proteins to differentiate $\mathrm{NiV}$ from $\mathrm{HeV}$ by Western blot [38]. In our study, 2B10 p4 antibody specifically captured native $\mathrm{HeV} \mathrm{P} / \mathrm{V} / \mathrm{W}$ proteins and could only detect $\mathrm{NiV}$ proteins at high virus concentration or by Western blot. These results suggest that the binding affinity of $2 \mathrm{~B} 10 \mathrm{p} 4$ could be influenced by how its epitope was presented by the P proteins of $\mathrm{NiV}$ and $\mathrm{HeV}$. In fact, we were unable to identify linear epitope of $2 \mathrm{~B} 10 \mathrm{p} 4$ from the NiV Malaysia P sequence despite knowing it should be located within the shared N-terminal sequence of $\mathrm{P} / \mathrm{V} / \mathrm{W}$ protein (a.a. 1-407). In contrast, polyclonal HMAF raised against $\mathrm{NiV}$ was able to recognize 6 individual plate-coated peptides in this region by direct ELISA (data not shown).

$\mathrm{NiV}$ and $\mathrm{HeV}$ soluble recombinant $\mathrm{G}$ proteins coated on beads had previously been developed and utilized in a Bio-Plex protein array to differentiate between infections with these viruses $[37,46]$. As the $G$ proteins of these viruses share $83.3 \%$ homology [19] and the assay would be assessing polyclonal antibodies present in clinical specimens, it is unclear to what extent the ability to differentiate between the viruses would be maintained on analysis of diverse specimens from humans, bats or pigs. One of the advantages of the antigen capture assay 
described here is that it is based on the $\mathrm{P}$ protein of NiV and $\mathrm{HeV}$ which is highly diverse and share only $67.6 \%$ homology [19], which may facilitate the ability to robustly differentiate among infections with henipaviruses.

Real time RT-PCR has been shown to detect Nipah virus with high sensitivity and specificity [28,29]. However, nested RT-PCR using broad-range primers and sequencing may be required to identify newly emerging henipaviruses [36,47]. Although further validation for our antigen capture assay will be needed once $\mathrm{HeV}$ and $\mathrm{NiV}$ infected tissue specimens are available, this relatively inexpensive and robust diagnostic tool could be useful in broad spectrum surveys for detection of henipaviruses.

\section{Conclusions}

Two monoclonal antibodies were selected to set up antigen capture ELISAs for Henipavirus. Mab $1 \mathrm{~A} 11 \mathrm{C} 1 \mathrm{rec}-$ ognized $\mathrm{C}$ terminus of $\mathrm{N}$ protein of both $\mathrm{NiV}$ and $\mathrm{HeV}$ with high sensitivity. 2B10 p4 was found to bind Hendra $\mathrm{P} / \mathrm{V} / \mathrm{W}$ with good specificity. While the applications of $\mathrm{NiV} / \mathrm{HeV}$ infection by our antigen capture ELISAs remain to be fully evaluated, we believe these assays could offer economical and rapid sample processing for any future outbreaks of henipaviruses.

\section{Methods}

\section{Virus stocks, cell lysates, and pig tissue suspensions}

Hendra virus strain 9409-30-1800 Australia was originated from a horse lung sample from Brisbane, Australia in 1994. Both Nipah virus strain SPB199901924 Malaysia prototype and strain SPB200401617 Bangladesh were isolated from CSF of patients in the 1999 and 2004 outbreaks, respectively. Lassa virus Josiah strain isolated from human in Sierra Leone was used as the control virus stock. Viruses were inoculated in Vero-E6 cell and propagated until CPE reached 3-4+ before harvest. Viruses were titrated by plaque assays on Vero-E6 cells as described [48]. The attached cells were scraped and centrifuged, washed before lysed in borate saline containing $1 \%$ Triton $\mathrm{X}-100, \mathrm{pH} 9$. The sample was frozen at $-70^{\circ} \mathrm{C}$ and gamma irradiated at $5 \times 10^{6} \mathrm{Rad}$. The resulting material was sonicated and centrifuged to obtain cell lysate. Control Vero cell lysate was made the same way except no virus infection was performed.

For pig tissue samples from 1999 Malaysia outbreak [10], 10\% (wt/vol) suspensions of thawed frozen tissue sections $(\sim 250 \mathrm{mg})$ were homogenized on ice in Hank's balance salt solution (HBSS)/5\% fetal calf serum with a plastic pestle and $250 \mathrm{mg}$ of alundum (Fischer Scientific, Pittsburgh, PA) in $15 \mathrm{~mL}$ conical tubes. The tissue suspensions were clarified by low speed centrifugation before using in antigen capture ELISA as follows.

\section{Nipah hybridomas and monoclonal antibodies}

Twenty five $\mu \mathrm{L}$ of Nipah virus Malaysian prototype stock was i.c. injected into suckling mice in BSL4 laboratory. The brain of the sick suckling mouse was taken out by day $3, \gamma$-irradiated and used for following immunizations. Four weeks old BALB/C mice (Charles River Laboratories, Wilmington, MA) were immunized i.p. with $10 \%$ suckling mouse brain, HBSS and 0.05 M Tris buffer, pH 9 emulsified with Ribi adjuvant (Ribi ImmunoChem Research Inc., Hamilton, MT) in $200 \mu \mathrm{L}$. Two booster injections of $100 \mu \mathrm{L}$ were given on days 21 and 35. Mice serum antibody titers were monitored by ELISA and IFA in between boosters. One hundred $\mu \mathrm{L}$ of brain homogenate without adjuvant was injected at day 56 and 4 days later, the splenocytes of the immunized mice were isolated and fused with NS-1 (TIB-18) myeloma cells. Hybridomas were screened for secretion for desired antibodies by ELISA and IFA. Western blot was used for confirmations of monoclonality and specificity of the antibody. Protein G $8 \mathrm{~mL}$ or Protein A $36 \mathrm{~mL}$ column connected to an ÄKTAprime ${ }^{\text {tw }}$ plus system (GE Healthcare, Piscataway, NJ) was used for purification of monoclonal antibody from supernatants from hybridoma cultures. Antibodies were concentrated in Amicon $50 \mathrm{~mL}$ Stirred Ultrafiltration Cells (Millipore, Billerica, MA). The isotype of purified monoclonal antibody was determined by IsoStrip Mouse Monoclonal Antibody Isotyping Kit (Roche Diagnostics, Indianapolis, IN).

\section{Western blot}

HEK 293T cells were transfected with expression plasmids containing $\mathrm{P}, \mathrm{V}, \mathrm{W}, \mathrm{C}$, or $\mathrm{N}$ as previously described [34]. Cells were lysed in RIPA buffer $(150 \mathrm{mM} \mathrm{NaCl}, 1 \%$ NP-40, $0.5 \%$ sodium deoxycholate, $0.1 \%$ SDS, $50 \mathrm{mM}$ Tris Buffer, $\mathrm{pH} 8$ ). Ten $\mu \mathrm{L}$ of cell lysate was separated on a NuPAGE ${ }^{\text {Tw }} 4-12 \%$ Bis-Tris gel (Invitrogen, Carlsbad, CA), then transferred onto a PVDF membrane by iBlot $^{\mathrm{mm}}$ Gel Transfer System (Invitrogen). After Blocking with PBS containing $0.05 \%$ Tween- 20 and $5 \%$ skim milk, the membrane was incubated with hybridoma cell supernatant overnight at $4{ }^{\circ} \mathrm{C}$. PBS containing $0.05 \%$ Tween- 20 was used for thorough washing before HRP- conjugated antibody was added to incubation. Signals were developed by using SuperSignal ${ }^{\text {mi }}$ West Dura Extended Duration Substrate (Thermo Scientific, Waltham, MA).

\section{Epitope mapping}

Non-overlapped 24, 25 or 26-mer peptides spanning Nterminal half (a.a. 1-407) sequence of Nipah $P$ protein (NCBI Reference Sequence, Accession no: NP_112022) and the entire sequence (a.a. 1-532) of Nipah $\mathrm{N}$ protein (NCBI Reference Sequence, Accession no: NP_112021) were synthesized and RP-HPLC purified by the Biotechnology Core Facility in CDC. Peptides were dissolved in 
water before transferring to microtiter plates, and dried at $37^{\circ} \mathrm{C}$ overnight as described [49]. The wells were blocked with $100 \mu \mathrm{L}$ of PBS containing $0.1 \%$ Tween-20 and 5\% skim milk for 1 hour then washed with PBS containing $0.1 \%$ Tween- 20 . The monoclonal antibody (2B10 p4 or $1 \mathrm{~A} 11 \mathrm{C} 1$ ) or polyclonal antibody (NiV HMAF, HeV HMAF, rabbit anti-HeV serum, NiV infected human convalescent or a pool of $\mathrm{NiV}$ seropositive swine sera) was diluted into $1 \mu \mathrm{g} / \mathrm{mL}$ (monoclonal) or 1 to 1000 (polyclonal) with blocking buffer. The antibody was added and incubated for 1 hour at $37^{\circ} \mathrm{C}$. The secondary HRP-conjugated goat anti-mouse IgG (Thermo Fisher Scientific, Rockford, IL), goat anti-rabbit IgG (Bio-Rad, Hercules, CA), mouse anti-human IgG Fc (Accurate, Westbury, $\mathrm{NY}$ ), or goat anti-swine IgG (KPL, Gaithersburg, MD) in 1:8000 was added after washing. After one hour of incubation, color development was measured as described in the following ELISA protocol.

\section{Antigen capture ELISA}

The design and setup of antigen capture ELISA for henipavirus were based on the assay developed for Ebola virus as described previously $[43,50]$. Five $\mu \mathrm{g} / \mathrm{mL}$ of monoclonal antibody (1A11 C1 or $2 \mathrm{~B} 10 \mathrm{p} 4)$ in $100 \mu \mathrm{L} /$ well were coated onto each well of microtiter plates (BD Falcon, San Jose, CA) overnight at $4^{\circ} \mathrm{C}$. Wells were blocked for an hour at $37^{\circ} \mathrm{C}$ with PBS containing $0.1 \%$ Tween-20 and $5 \%$ skim milk then washed with PBS containing $0.1 \%$ Tween20 , which also included in subsequent steps. Henipavirus stocks, infected Vero-E6 cell lysate or euthanized pig tissue suspension were serial-diluted with PBS containing $0.1 \%$ Tween- 20 and $5 \%$ skim milk in $100 \mu \mathrm{L}$ on plate then incubated for one hour at $37^{\circ} \mathrm{C}$. Rabbit anti-HeV polyclonal antibody diluted 2000 fold was added and incubated for an hour at $37^{\circ} \mathrm{C}$. The wells were incubated with goat anti-rabbit HRP conjugate (Bio-Rad) at a dilution of 1:8000 for 1 hour at $37^{\circ} \mathrm{C}$. The peroxidase reaction was developed with ABTS (2, 2'-azino-bis (3-ethylbenzthiazoline-6-sulphonic acid)) substrate system (KPL) for $30 \mathrm{~min}$ and optical density (OD) was read at $410 \mathrm{~nm}$ (Dynatech MR5000). The OD value subtracted by the background value of control uninfected Vero cell lysate or tissue suspension incubated with coated Marburg virus HMAF (1:1000) was indicated as "Adjusted OD". Test samples were considered positive if their mean OD were greater than the mean OD of uninfected Vero cell lysate or tissue suspension incubated with coated monoclonal antibodies plus 3 times of their standard deviation (indicated as the signal cutoff value).

\section{Competing interests}

The authors declare that they have no competing interests.

\section{Authors' contributions}

CFC performed much of the Nipah and Hendra virus Western blots, ELISAs, and drafted the manuscripts, MKL prepared transfected 293T cell lysates containing
NiV proteins and contributed to manuscript preparation, PAR and CFS provided valuable opinions to the results and also contributed to manuscript preparation, PER oversaw the overall assay designs, coordinated study support, and assisted manuscript preparation and submission. All authors have read and approved the final version of this manuscript.

\section{Acknowledgements}

Hybridoma subcloning, monoclonal antibody purification and peptide synthesis were performed by Suyu Ruo, members in Biologics Branch and Biotechnology Core Facility of CDC. We would like to acknowledge Zachary Reed, David Miller, Shelley Campbell, Aridth Gibbons, Gregory Kocher, and Deborah Cannon for their assistance in reagent preparation and data collection. Michael Lo was supported by an American Society for Microbiology postdoctoral fellowship. The authors also thank to Drs. Brian Harcourt and Wun-Ju Shieh for providing RT-PCR and immunohistochemistry data of 1999 Malaysia outbreak, and Dr. Stuart Nichol for his support in this study.

\section{Author Details}

'Special Pathogens Branch, Division of Viral and Rickettsial Diseases, Centers for Disease Control and Prevention, Atlanta, Georgia, USA and 2Measles, Mumps, Rubella and Herpes Viruses Laboratory Branch, Division of Viral Diseases, Centers for Disease Control and Prevention, Atlanta, Georgia, USA

Received: 5 May 2010 Accepted: 3 June 2010 Published: 3 June 2010

\section{References}

1. Wild TF: Henipaviruses: a new family of emerging Paramyxoviruses. Pathol Biol 2009, 57:188-196.

2. Lo MK, Rota PA: The emergence of Nipah virus, a highly pathogenic paramyxovirus. J Clin Virol 2008, 43:396-400.

3. Guillaume V, Wong KT, Looi RY, Georges-Courbot MC, Barrot L, Buckland R, Wild TF, Horvat B: Acute Hendra virus infection: Analysis of the pathogenesis and passive antibody protection in the hamster model. Virology 2009, 387:459-465.

4. Hsu VP, Hossain MJ, Parashar UD, Ali MM, Ksiazek TG, Kuzmin I, Niezgoda M, Rupprecht C, Bresee J, Breiman RF: Nipah virus encephalitis reemergence, Bangladesh. Emerg Infect Dis 2004, 10:2082-2087.

5. Playford EG, McCall B, Smith G, Slinko V, Allen G, Smith I, Moore F, Taylor C, Kung $\mathrm{YH}$, Field $\mathrm{H}$ : Human Hendra virus encephalitis associated with equine outbreak, Australia, 2008. Emerg Infect Dis 2010, 16:219-223.

6. Wacharapluesadee S, Boongird K, Wanghongsa S, Ratanasetyuth N, Supavonwong P, Saengsen D, Gongal GN, Hemachudha T: A longitudinal study of the prevalence of Nipah virus in Pteropus lylei bats in Thailand: Evidence for seasonal preference in disease transmission. Vector Borne Zoonotic Dis 2010, 10:183-190.

7. Yob JM, Field H, Rashdi AM, Morrissy C, van der Heide B, Rota P, bin Adzhar A, White J, Daniels P, Jamaluddin A, Ksiazek T: Nipah virus infection in bats (order Chiroptera) in peninsular Malaysia. Emerg Infect Dis 2001 7:439-441.

8. Field H, Young P, Yob JM, Mills J, Hall L, Mackenzie J: The natural history of Hendra and Nipah viruses. Microbes Infect 2001, 3:307-314.

9. Eaton BT, Broder CC, Middleton D, Wang LF: Hendra and Nipah viruses: different and dangerous. Nat Rev Microbiol 2006, 4:23-35.

10. Chua KB, Bellini WJ, Rota PA, Harcourt BH, Tamin A, Lam SK, Ksiazek TG, Rollin PE, Zaki SR, Shieh W, et al.: Nipah virus: a recently emergent deadly paramyxovirus. Science 2000, 288:1432-1435.

11. Murray K, Selleck P, Hooper P, Hyatt A, Gould A, Gleeson L, Westbury H, Hiley L, Selvey L, Rodwell B: A morbillivirus that caused fatal disease in horses and humans. Science 1995, 268:94-97.

12. Harcourt BH, Lowe L, Tamin A, Liu X, Bankamp B, Bowden N, Rollin PE, Comer JA, Ksiazek TG, Hossain MJ, et al.: Genetic characterization of Nipah virus, Bangladesh, 2004. Emerg Infect Dis 2005, 11:1594-1597.

13. Hossain MJ, Gurley ES, Montgomery JM, Bell M, Carroll DS, Hsu VP, Formenty P, Croisier A, Bertherat E, Faiz MA, et al: Clinical presentation of Nipah virus infection in Bangladesh. Clin Infect Dis 2008, 46:977-984.

14. Chadha MS, Comer JA, Lowe L, Rota PA, Rollin PE, Bellini WJ, Ksiazek TG, Mishra A: Nipah virus-associated encephalitis outbreak, Siliguri, India. Emerg Infect Dis 2006, 12:235-240.

15. Voelker R: Promising antibody fights lethal viruses. JAMA 2009, 302:2643 
16. Daniels P, Ksiazek T, Eaton BT: Laboratory diagnosis of Nipah and Hendra virus infections. Microbes Infect 2001, 3:289-295.

17. Bossart KN, Zhu Z, Middleton D, Klippel J, Crameri G, Bingham J, McEachern JA, Green D, Hancock TJ, Chan YP, et al: A neutralizing human monoclonal antibody protects against lethal disease in a new ferret model of acute Nipah virus infection. PLoS Pathog 2009, 5:e1000642.

18. Harcourt BH, Tamin A, Ksiazek TG, Rollin PE, Anderson LJ, Bellini WJ, Rota PA: Molecular characterization of Nipah virus, a newly emergent paramyxovirus. Virology 2000, 271:334-349.

19. Wang L, Harcourt BH, Yu M, Tamin A, Rota PA, Bellini WJ, Eaton BT: Molecular biology of Hendra and Nipah viruses. Microbes Infect 2001, 3:279-287.

20. Mayo MA: Names of viruses and virus species - an editorial note. Arch Virol 2002, 147:1463-1464

21. Shiell BJ, Gardner DR, Crameri G, Eaton BT, Michalski WP: Sites of phosphorylation of $\mathrm{P}$ and $\mathrm{V}$ proteins from Hendra and Nipah viruses: newly emerged members of Paramyxoviridae. Virus Res 2003, 92:55-65.

22. Chen JM, Yu M, Morrissy C, Zhao YG, Meehan G, Sun YX, Wang QH, Zhang W, Wang LF, Wang ZL: A comparative indirect ELISA for the detection of henipavirus antibodies based on a recombinant nucleocapsid protein expressed in Escherichia coli. J Virol Methods 2006, 136:273-276.

23. Eshaghi M, Tan WS, Ong ST, Yusoff K: Purification and characterization of Nipah virus nucleocapsid protein produced in insect cells. J Clin Microbiol 2005, 43:3172-3177.

24. Juozapaitis M, Serva A, Zvirbliene A, Slibinskas R, Staniulis J, Sasnauskas K, Shiell BJ, Wang LF, Michalski WP: Generation of henipavirus nucleocapsid proteins in yeast Saccharomyces cerevisiae. Virus Res 2007, 124:95-102

25. Yu F, Khairullah NS, Inoue S, Balasubramaniam V, Berendam SJ, Teh LK, Ibrahim NS, Abdul Rahman S, Hassan SS, Hasebe F, et al:: Serodiagnosis using recombinant Nipah virus nucleocapsid protein expressed in Escherichia coli. J Clin Microbiol 2006, 44:3134-3138.

26. Crameri G, Wang LF, Morrissy C, White J, Eaton BT: A rapid immune plaque assay for the detection of Hendra and Nipah viruses and antivirus antibodies. J Virol Methods 2002, 99:41-51.

27. Tamin A, Harcourt BH, Lo MK, Roth JA, Wolf MC, Lee B, Weingartl H, Audonnet JC, Bellini WJ, Rota PA: Development of a neutralization assay for Nipah virus using pseudotype particles. J Virol Methods 2009, 160:1-6.

28. Guillaume V, Lefeuvre A, Faure C, Marianneau P, Buckland R, Lam SK, Wild TF, Deubel V: Specific detection of Nipah virus using real-time RT-PCR (TaqMan). J Virol Methods 2004, 120:229-237.

29. Gurley ES, Montgomery JM, Hossain MJ, Bell M, Azad AK, Islam MR, Molla MA, Carroll DS, Ksiazek TG, Rota PA, et al:: Person-to-person transmission of Nipah virus in a Bangladeshi community. Emerg Infect Dis 2007 , 13:1031-1037.

30. Muller JD, McEachern JA, Bossart KN, Hansson E, Yu M, Clavijo A, Hammond JM, Wang LF: Serotype-independent detection of foot-andmouth disease virus. J Virol Methods 2008, 151:146-153.

31. Ferris NP, Abrescia NG, Stuart DI, Jackson T, Burman A, King DP, Paton DJ: Utility of recombinant integrin alpha $v$ beta6 as a capture reagent in immunoassays for the diagnosis of foot-and-mouth disease. J Virol Methods 2005, 127:69-79.

32. Kulkarni S, Volchkova V, Basler CF, Palese P, Volchkov VE, Shaw ML: Nipah virus edits its $\mathrm{P}$ gene at high frequency to express the $\mathrm{V}$ and $\mathrm{W}$ proteins. J Virol 2009, 83:3982-3987.

33. Sleeman K, Bankamp B, Hummel KB, Lo MK, Bellini WJ, Rota PA: The C, V and $W$ proteins of Nipah virus inhibit minigenome replication. $J$ Gen Virol 2008, 89:1300-1308.

34. Lo MK, Harcourt BH, Mungall BA, Tamin A, Peeples ME, Bellini WJ, Rota PA: Determination of the henipavirus phosphoprotein gene mRNA editing frequencies and detection of the $C, V$ and $W$ proteins of Nipah virus in virus-infected cells. J Gen Virol 2009, 90:398-404.

35. lehle C, Razafitrimo G, Razainirina J, Andriaholinirina N, Goodman SM, Faure C, Georges-Courbot MC, Rousset D, Reynes JM: Henipavirus and Tioman virus antibodies in pteropodid bats, Madagascar. Emerg Infect Dis 2007, 13:159-161.

36. Drexler JF, Corman VM, Gloza-Rausch F, Seebens A, Annan A, Ipsen A, Kruppa T, Muller MA, Kalko EK, Adu-Sarkodie Y, et al: Henipavirus RNA in African bats. PLoS One 2009, 4:e6367.
37. Hayman DT, Suu-Ire R, Breed AC, McEachern JA, Wang L, Wood JL, Cunningham AA: Evidence of henipavirus infection in West African fruit bats. PLoS One 2008, 3:e2739.

38. Berhane Y, Berry JD, Ranadheera C, Marszal P, Nicolas B, Yuan X, Czub M, Weingartl $\mathrm{H}$ : Production and characterization of monoclonal antibodies against binary ethylenimine inactivated Nipah virus. J Viro/ Methods 2006, 132:59-68.

39. Zhu Z, Bossart KN, Bishop KA, Crameri G, Dimitrov AS, McEachern JA, Feng $Y$, Middleton D, Wang LF, Broder CC, Dimitrov DS: Exceptionally potent cross-reactive neutralization of Nipah and Hendra viruses by a human monoclonal antibody. J Infect Dis 2008, 197:846-853.

40. Xiao C, Liu Y, Jiang Y, Magoffin DE, Guo H, Xuan H, Wang G, Wang LF, Tu C: Monoclonal antibodies against the nucleocapsid proteins of henipaviruses: production, epitope mapping and application in immunohistochemistry. Arch Virol 2008, 153:273-281.

41. Chan YP, Koh CL, Lam SK, Wang LF: Mapping of domains responsible for nucleocapsid protein-phosphoprotein interaction of henipaviruses. J Gen Virol 2004, 85:1675-1684.

42. Eshaghi M, Tan WS, Yusoff $\mathrm{K}$ : Identification of epitopes in the nucleocapsid protein of Nipah virus using a linear phage-displayed random peptide library. J Med Virol 2005, 75:147-152.

43. Ksiazek TG, Rollin PE, Jahrling PB, Johnson E, Dalgard DW, Peters CJ: Enzyme immunosorbent assay for Ebola virus antigens in tissues of infected primates. J Clin Microbiol 1992, 30:947-950.

44. Saijo M, Georges-Courbot MC, Fukushi S, Mizutani T, Philippe M, Georges AJ, Kurane I, Morikawa S: Marburgvirus nucleoprotein-capture enzymelinked immunosorbent assay using monoclonal antibodies to recombinant nucleoprotein: detection of authentic Marburgvirus. Jpn J Infect Dis 2006, 59:323-325.

45. Maisner A, Neufeld J, Weingartl H: Organ- and endotheliotropism of Nipah virus infections in vivo and in vitro. Thromb Haemost 2009, 102:1014-1023.

46. Bossart KN, McEachern JA, Hickey AC, Choudhry V, Dimitrov DS, Eaton BT, Wang LF: Neutralization assays for differential henipavirus serology using Bio-Plex protein array systems. J Virol Methods 2007, 142:29-40.

47. Tong S, Chern SW, Li Y, Pallansch MA, Anderson L: Sensitive and broadly reactive reverse transcription-PCR assays to detect novel paramyxoviruses. J Clin Microbiol 2008, 46:2652-2658.

48. Gupta M, Mahanty S, Bray M, Ahmed R, Rollin PE: Passive transfer of antibodies protects immunocompetent and imunodeficient mice against lethal Ebola virus infection without complete inhibition of viral replication. J Virol 2001, 75:4649-4654.

49. Porzig R, Singer D, Hoffmann R: Epitope mapping of mAbs AT8 and Tau5 directed against hyperphosphorylated regions of the human tau protein. Biochem Biophys Res Commun 2007, 358:644-649.

50. Ksiazek TG, Rollin PE, Williams AJ, Bressler DS, Martin ML, Swanepoel R, Burt FJ, Leman PA, Khan AS, Rowe AK, et al:: Clinical virology of Ebola hemorrhagic fever (EHF): virus, virus antigen, and IgG and IgM antibody findings among EHF patients in Kikwit, Democratic Republic of the Congo, 1995. J Infect Dis 1999, 179(Suppl 1):S177-187.

doi: $10.1186 / 1743-422 X-7-115$

Cite this article as: Chiang et al., Use of monoclonal antibodies against Hendra and Nipah viruses in an antigen capture ELISA Virology Journal 2010, 7:115 